\title{
A Tao rendszer hatásainak felmérése a magyar kosárlabda csapatoknál
}

\section{Assessing Effects of the TAO System on Hungarian Basketball Teams}

\author{
Váczi Péter, Boda Eszter, Herpainé Lakó Judit, Müller Anetta \\ Eszterházy Károly Egyetem, Sporttudományi Intézet, Eger
}

\begin{abstract}
Absztrakt: Vizsgálatunk célja az volt, hogy megpróbáljuk felmérni és bemutatni, hogy a 2011-ben bevezetett, a látványsportokat támogató társasági adórendszer milyen hatással volt a kosárlabda bajnokságokban induló klubokra. Célunk volt megvizsgálni azt, hogy több szempontot figyelembe véve ez a rendszer segítette vagy inkább gátolta a kosárlabda sportágban tevékenykedó sportklubokat. Kérdő́ives felmérésünket az összes első-, másod- és harmadosztályban tevékenykedő klubnak elküldtük. 53 klub töltötte ki kérdóívünket. A kapott eredményeink azt mutatták, hogy nagy segítséget jelent a Tao rendszer a klubok számára.
\end{abstract}

Kulcsszavak: Tao rendszer, kosárlabda, régiók

Abstract: The aim of our research was to show and analyse how the corporate tax system (introduced in 2011) has influenced the economic aspects of basketball in Hungary. We analysed what advantages and disadvantages this corporate tax system has brought to basketball clubs. 53 clubs filled our questionnaire. The obtained results showed us that the Tao system meant considerable help for the basketball clubs.

Keywords: Tao system, basketball, regions

\section{Bevezetés}

2011-ben a magyar országgyülés elfogadta azt a törvénymódosítást, amely lehetővé tette, hogy a gazdasági társaságok nyereségadójukból támogathatnak sportegyesületeket. Alapvetően ez egy olyan támogatási rendszer, amelyet ugyan nem direkt módon ad az állam, hanem a cégek. Azaz az állam mond le egy bevételi forrásról a sportágak javára. Ezt a támogatást öt látványsport részére nyújthatják, a labdarúgásnak, a kézilabdának, a kosárlabdának, a jégkorongnak és a vízilabdának. A sportágak kiválasztásában a magyar hagyományok és a sportágak globális népszerűsége is döntő volt. Nem meglepő módon ez a fajta támogatási rendszer egyáltalán nem mondható általánosnak a világban. Leginkább azért van szükség erre a támogatási rendszerre, mert Magyarországon még nem alakult ki teljesen az a piaci alapon működő sportrendszer, amely elsődlegesen a kelet-közép európai országokra jellemző (Andersen, Houlihan és Roglan, 2015).
A Tao támogatást az egyesületek, szövetségek utánpótlás nevelés finanszírozására, infrastruktúrafejlesztésre, képzéssel összefüggő feladatokra és személyi jellegű ráfordításokra használhatják fel. Erről a rendszerről az mondható el, hogy nagy segítséget jelentett az öt látványsport fejlődése, müködése okán. Az is látható, hogy a támogatások nagyobb része a labdarúgásba áramlott. Az első, a 2011-es Tao-s évben az igényelt 33 milliárdos támogatásból 21 milliárd a magyar labdarúgásba került. ${ }^{1}$ 2013-ban változtatott a magyar állam a rendszeren. Jelentősen lecsökkentette az adott támogatások után a cégeknek jutatott kedvezmények mértékét. A 2013. május 19-én hatályba lépett törvénymódosítás kiegészítő sportfejlesztési támogatás befizetésének kötelezettségét írta elő azoknak a vállalkozásoknak, amelyek élni kívántak a sporttámogatások Tao-s kedvezményével. Az új szabály hatására a kedvezmény mértéke a korábbi negyedére

\footnotetext{
${ }^{1}$ http://sport365.hu/magyar-foci,nb1-labdarugas,ez-ta(h)

o-sag-33-milliard-forint-valos-tortenete, 20550
} 
csökkent. A módosítás ellenére a Tao-s rendszer támogatása nélkül már-már életképtelenné válhatna az öt látványsportban működő sportklubok egy jelentős része, hiszen a Tao-s támogatások mellett a klasszikus szponzoráció nagy része eltünt az élsportból. Vizsgálatunk célja az volt, hogy felmérjük és bemutassuk, milyen hatással volt a kosárlabda bajnokságokban induló klubokra a 2011-ben bevezetett, a látványsportokat támogató társasági adórendszer. Célunk volt megvizsgálni azt, hogy több szempontot figyelembe véve, ez a rendszer segítette vagy inkább gátolta a kosárlabda sportágban tevékenykedő sportklubokat. Feltételeztük, hogy a Tao 2011-es indulása óta a csapatok nagyobb része folyamatosan pályázott a megszerezhető támogatásra, illetve a klubok többségének elengedhetetlen segítséget jelent ez a fajta támogatás.

\section{Módszerek}

$\mathrm{Az}$ ebben a tanulmányban ismertetett Egyáltalán nem segített I Kis mértékben segített I Közepes mértékben segített Jelentős segítség volt

Tao nélkül nem valósult volna meg eredmények egy nagyobb, a magyar kosárlabdázásban használt marketing és menedzsment módszerek vizsgálatával foglalkozó kutatás Tao rendszerrel foglalkozó részeiből került ki. A kérdőíves kutatásban a válaszaikat online kitöltéssel küldték vissza a csapatok ( $\mathrm{n}=53)$. Az 53-ból 12 csapat az első, 21 csapat a másod-, 20 csapat pedig a harmadosztályban versenyez.

\section{Eredmények}

\section{Stabil gazdálkodás}

Eredményeink rámutattak arra, hogy a látványsportokat támogató Tao rendszer döntő fontosságú tényezővé vált a kosárlabda klubok életében. A vizsgált klubok 84\%-ánál jelentős segítséget nyújtott a működéshez, sőt e nélkül nem valósulhatott volna meg a stabil gazdálkodás. Mindösszesen a válaszadók 14\%-a vélekedett úgy, hogy nem igazán döntő fontosságú a gazdálkodásukban a Tao támogatás.

2. ábra. A Tao rendszer szerepe a beruházások megvalósításában [Forrás: saját szerkesztés]

\section{Utánpótlásfejlesztés}

A legfontosabb kérdés arra vonatkozott, hogy a Tao rendszer milyen segítséget nyújtott az esetén. A válaszadók 61,4\%-a nyilatkozott úgy, hogy Tao nélkül nem tudtak volna belevágni a beruházási projektekbe.

\section{$2 \%$ \\ $2 \%$ \\ $12 \%$ \\ $44 \%$ \\ $40 \%$} árlabda egyesületek gazdálkodásában ( $\mathrm{n}=53)$ [Forrás: saját szerkesztés]

$\begin{array}{ll}\text { Egyáltalán nem segített } & 9,1 \% \\ \text { Kis mértékben segített } & 0 \% \\ \text { Közepes mértékben segített } & 9,1 \% \\ \text { Jelntős segítség volt } & 20,5 \% \\ \begin{array}{l}\text { Tao nélkül nem valósult } \\ \text { volna meg }\end{array} & 61,4 \%\end{array}$
leteknek az aránya, akik kiemelt segítségnek tartják a Tao rendszert a beruházások megvalósulása

\section{Beruházások megvalósítása}

Jelentős, összesen 81,9\%-os azoknak az egyesüutánpótlás fejlesztéshez. Nem vitás, hogy a Tao rendszerrel a kormányzat egyik fö célja az igazolt sportolók számának az emelése volt, ehhez viszont 
az utánpótlás nevelés szintjének az emelése kulcskérdés. Nem véletlenül tartozik az utánpótlással kapcsolatos Tao-s fejlesztésekhez a legkevesebb mértékű kötelező önerő. A válaszokból világosan kitűnik, összesen 90\%-os arányban gondolják úgy

$\begin{array}{ll}\text { Egyáltalán nem segített } & 2 \% \\ \text { Kis mértékben segített } & 0 \% \\ \text { Közepes mértékben segített } & 8 \% \\ \text { Jelntős segítség volt } & 36 \% \\ \begin{array}{l}\text { Tao nélkül nem valósult } \\ \text { volna meg }\end{array} & 54 \% \\ \end{array}$

3. ábra. A Tao rendszer jelentősége az utánpótlás fejlesztésben [Forrás: saját szerkesztés]

\section{Tao pályázat}

Az eredményeink azt mutatják, hogy a csapatok több mint $80 \%$-a minden évben pályázott a Tao-s támogatásokra.

Ez is azt bizonyítja, hogy a fejlesztésekhez, az éves költségvetéshez szinte már-már elengedhetetlen a Tao támogatások segítsége. Az eddigi kérdésekre adott válaszokból csupa pozitív jellemzőt tudtunk elmondani, leszűrni a Tao látványsportot támogató rendszerről.

Beszélnünk kell viszont a rendszer egyik nagy hátrányáról is, arról, hogy a Tao támogatások cégek általi kifizetése mellett klasszikus szponzoráció - amikor egy cég a saját nyereségéből szponzorál a kérdőívet visszaküldő klubok, hogy az utánpótlás fejlesztéshez fontos vagy nélkülözhetetlen segítséget jelentett a Tao-s rendszer.
- egyre kevesebb érkezik a sportba.

\section{Klasszikus szponzoráció}

A válaszadó egyesületek több mint 60\%-a úgy érzi, hogy sokkal kevesebb vagy kevesebb klasszikus szponzorációs támogatás érkezik a Tao rendszer bevezetése óta. Ez egy olyan adat, amit komolyan kell venni, és a sportban dolgozó vezetőknek előre kell már most gondolkozniuk, hogy a Tao rendszer esetleges megszűnése esetén milyen alternatívákkal tudják a sportegyesületek működését, fejlődését továbbra is biztosítani.

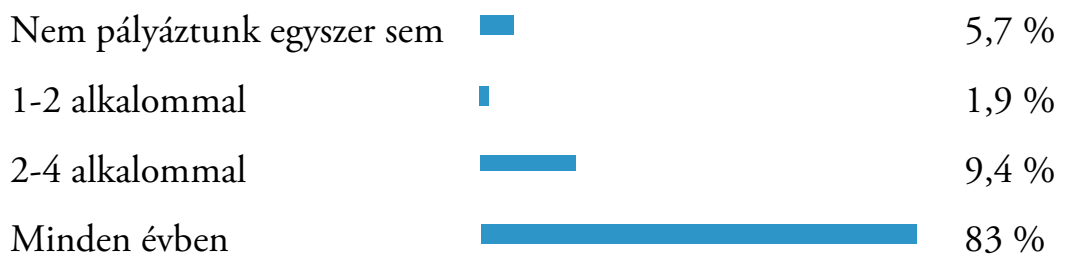

4. ábra. Tao-s pályázat gyakorisága [Forrás: saját szerkesztés]

Sokkal kevesebb

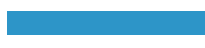

Kevesebb

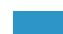

Nagyságrendileg ugyanannyi

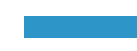

Több érkezik
$47,2 \%$

$9,4 \%$

5. ábra. A klasszikus szponzoráció alakulása a Tao-s rendszer bevezetése óta [Forrás: saját szerkesztés]

\section{Megbeszélés}

A kosárlabda csapatok döntő többségének markáns segítség volt a Tao-s rendszer ahhoz, hogy

a céljaikat, beruházásaikat megvalósítsák. Ezzel 
összefüggésben az is látszik, hogy pontosan ezen ok miatt folyamatosan pályáztak is a látványsportok támogatását elősegítő Tao-s támogatásokra. Ugyanakkor azt is meg kell jegyezni, hogy a Tao támogatások elindításával a klasszikus szponzorációs bevételek drasztikusan csökkentek. Éppen ezért a sport legfelső irányító testületeinek erősen el kell gondolkozni azon, hogy a Tao rendszer esetleges befejeződése után miképpen tudnak az egyesületek továbbra is jól müködni, vagy egyáltalán életben maradni.

\section{Irodalom}

1. Pepple, J. (2010): Soccer, The left, \& the farce of multiculturalism. Authorhouse publishing.

2. Andersen, S.S., Houlihan, B. és Roglan, L.T. (2015): Managing elite sport systems. Research and Practice Routledge Publishing.

3. Sport 365 (2012): Ez TA(H)O-ság: 33 milliárd forint valós története. http://sport365.hu/ magyar-foci,nb1-labdarugas,ez-ta(h)o-sag33-milliard-forint-valos-tortenete, 20550 (Letöltés: 2016.10.05.)

4. Szűcs Péter (2012): Utolsó pillanatban bedobott mentööv - TAO a kosárlabdában. http://kosar. blog.hu/2012/11/13/utolso_pillanatban_bedobott_mentoov_a_tao_a_kosarlabdaban (Letöltés: 2016.10.05.) 